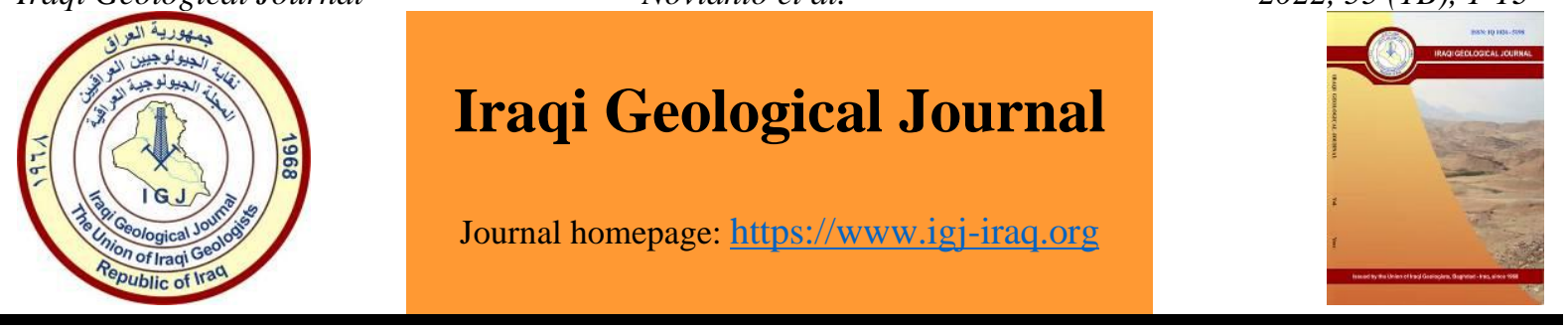

\title{
Structure Boundary Separating using Gravity Data for Central and Southern Parts of the East Java Basin Beneath the Quaternary Volcanic Deposits
}

\author{
Ardian Novianto $^{1}$,*, Sutanto ${ }^{1}$, Suharsono $^{1}$, Carolus Prasetyadi $^{1}$ and Jatmiko Setiawan $^{1}$ \\ Geological Engineering UPN "Veteran” Yogyakarta, Indonesia \\ Correspondence: ardian.novianto@upnyk.ac.id
}

Received:
28 September 2021

Accepted:

30 November 2021

Published:

28 February 2022

\begin{abstract}
Stratigraphic interpretation shows that the relationship between Cenozoic volcanic rocks deposited in the Southern Mountains and marine clastic volcanic rocks in the Kendeng Basin possibly forms a stratigraphic transition bordered by the major fault that is yet to be defined. The thick Quaternary volcanic deposits obstruct field observation on the surface. Miocene outcrops in limited presence are found on the volcanic slope, positioned relatively more to the north than the same outcrop. This feature indicates major thrusting in southern Java that moved it to the north. The gravity data analysis was used to obtain the field observation and identify the subsurface geology. Total Horizontal Derivative analysis of the gravity data showed a major fault boundary with a relative west-east direction separating the high Bouguer anomaly area in the south from a large negative area of about $-50 \mathrm{mGal}$ in the north. Second Vertical Derivative analysis reconstructed the fault slope direction and showed a south-facing slope with a large angle. Based on the combination of the surface data and the subsurface analysis, the boundary is a major fault with a west-east direction on the south side of the Quaternary volcanic range and a south-facing slope. It is interpreted as the result of the compressive tectonics that formed the fold-thrust belt system.
\end{abstract}

Keywords: East Java Basin; Fold-Thrust Belt System; Derivative gravity

\section{Introduction}

The physiographic of East Java, Indonesia, from the north to the south can be generally divided into three parts, namely Rembang, Kendeng, and Southern Mountains Zones (Smyth et al. 2005; Smyth et al. 2008). The Kendeng Zone is separated from the Southern Mountains by an area composed of volcanoes and Quaternary volcanic deposits known as the Ngawi subzone (Setiaji et al. 2016; Van Bemmelen, 1949) (Fig. 1). This zone is a sedimentary basin with a relative west-east orientation and divides East Java into three basins: the northern, central, and southern basins. Meanwhile, the Rembang Zone represents a basin at the edge of the Sunda Shelf composed of shallow marine deposits. To the south, there is a deep basin filled with deep-sea clastic volcanic deposits, otherwise known as the Kendeng Basin. Finally, the southernmost basin consists of Eocene-Miocene volcanic deposits known as the Early Cenozoic Southern Mountain Arc.

These basins share boundaries in the form of geological features: the Rembang and the Kendeng Basins are separated by the Randublatung High identified as a faulting block extending west-east

DOI: 10.46717 /igj.55.1B.1Ms-2022-02-17 
(Prasetyadi et al. 2016), and the Kendeng Basin and the Southern Mountains by a young Quaternary volcanic arc. The Quaternary volcanic deposits pose significant challenges in depicting subsurface geology. The stratigraphic or structural feature separating the Kendeng Basin from the Southern Mountains is not identifiable from the surface. Some scholars have defined the two basins based solely on morphological conditions distinguishing the Southern Mountains from the Quaternary volcanic deposits, implying that the precise boundaries have yet to be identified. This problem, however, can be addressed by a subsurface study using the gravity method to analyze the boundary between the Kendeng Basin and the Southern Mountains.

The Quaternary Volcanic Arc Line occupies the southern part of East Java and covers most of the southern part of the Kendeng Basin. This young volcanic deposit has been active since the Late Miocene (Smyth et al. 2005). It is interpreted as thick deposits, which raises a problem in the subsurface interpretation of the developing stratigraphy and geological structures, especially at the interface between the Kendeng Basin and the Southern Mountains. The stratigraphy of the Southern Mountains can be recognized from the Eocene-Miocene outcrops developing as siliciclastic, volcaniclastic, volcanic, and carbonate sediments. On the contrary, rocks of the same age constituting the Kendeng Basin are covered by the Quaternary volcanic deposits and are generally not visible on the surface. The interface between the two zones is interpreted as a stratigraphic transition from volcanic arc products to volcanogenic and pelagic sediments. During Oligocene-Miocene, the volcanic arc products filled the Kendeng Basin in the north and caused sediment loading, creating a deep flexural basin (Waltham et al. 2008). Rocks in the Kendeng Basin are rarely exposed, but interpretation shows that the rock sequence thickens to the south towards the Southern Mountains (Hall et al. 2007).

In general, rocks in the Southern Mountains are currently sloping to the south with low dip angles where contact with rocks in the Kendeng Basin in the north is unexposed. As a result, the interzonal boundaries are currently not identifiable. Some arguments connect the two basins with sediments that change gradually and experience tectonics producing anticline remnants with an eroded limb in the north. Other researchers suggest that the interzonal boundary is a faulting block formed due to extensional tectonics. However, the idea of extensional tectonics as the forces generating the fault block raises objections, as evidenced by satellite image analysis and microtectonics studies that conclude the slopes of Baturagung, south of Bayat (Jiwo Hill), Central Java, Indonesia, as a result of a compressive tectonic regime (Husein et al. 2008).

Various possible tectonics acting on the southern part of the East Java Basin indicate compressive tectonics. These compressive tectonics concept conforms to the subduction concept because of the movement of the Gondwana microcontinent in southern Java during the Cenozoic. Several experts, e.g., Hall et al. (2007), have put forward relevant indications as inferred from the well-developed compressive tectonics in the Southern Mountains that generate a thrust fault uplifting the old rocks to the north. Husein et al. (2008) provides the surface evidence to the rock displacement, that is, a thrust fault with an imbricate fan system and a duplex structure in the Tegalrejo area, south of Bayat, Central Java. The thrust fault is interpreted as being formed at the base of the northern mountain range and spanning to the northern edge of the Wonosari Basin (depression), which is the northern part of the Southern Mountains (Hall et al. 2007). The position of the northern boundary of this thrust fault system, which marks the interface between the Kendeng Basin and the Southern Mountains, remains open to debate. Because of the overlying Quaternary volcanic deposits, the concept of the thrust fault is not indicated. This study sought to determine the northern boundary of the thrust fault system in a subsurface study using the gravity method. The hydrocarbon seeps can draw the fault position (Awadh et al. 2013). The determination of fault position will have implications for the concept of hydrocarbon exploration, especially for the potential of reservoir rocks which are interpreted to form structures trap due to compression tectonic processes. 


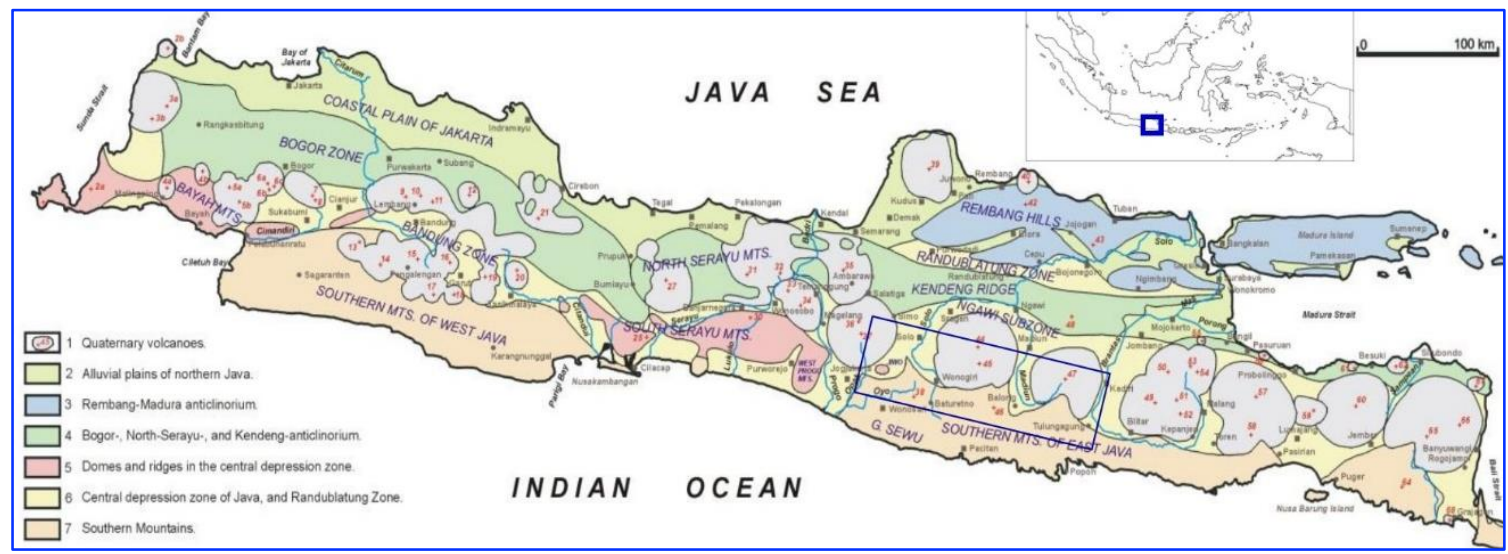

Fig.1. Schematic physiographic map of Java and Madura (Indonesia) divides eastern Java into several physiographic zones and shows the distribution of Quaternary volcanic deposits in the south (after Van Bemmelen, 1970) (Setiaji et al. 2016). The blue-line box marks the research location

\section{Tectonic Setting}

The compressive tectonics at work along southern Java is a long-standing concept that continues to develop. This area, lying in a forearc tectonic setting, experienced compression forces from the subduction process occurring in several periods in the Cenozoic. Some evidence of this compressive tectonic system has been found throughout the island, especially in the east. The system generated major thrusting of varying intensity in the south and displaced Paleogene volcanic rocks to the north (Hall et al. 2007), although the intensity becomes increasingly weaker eastward (Fig. 2).

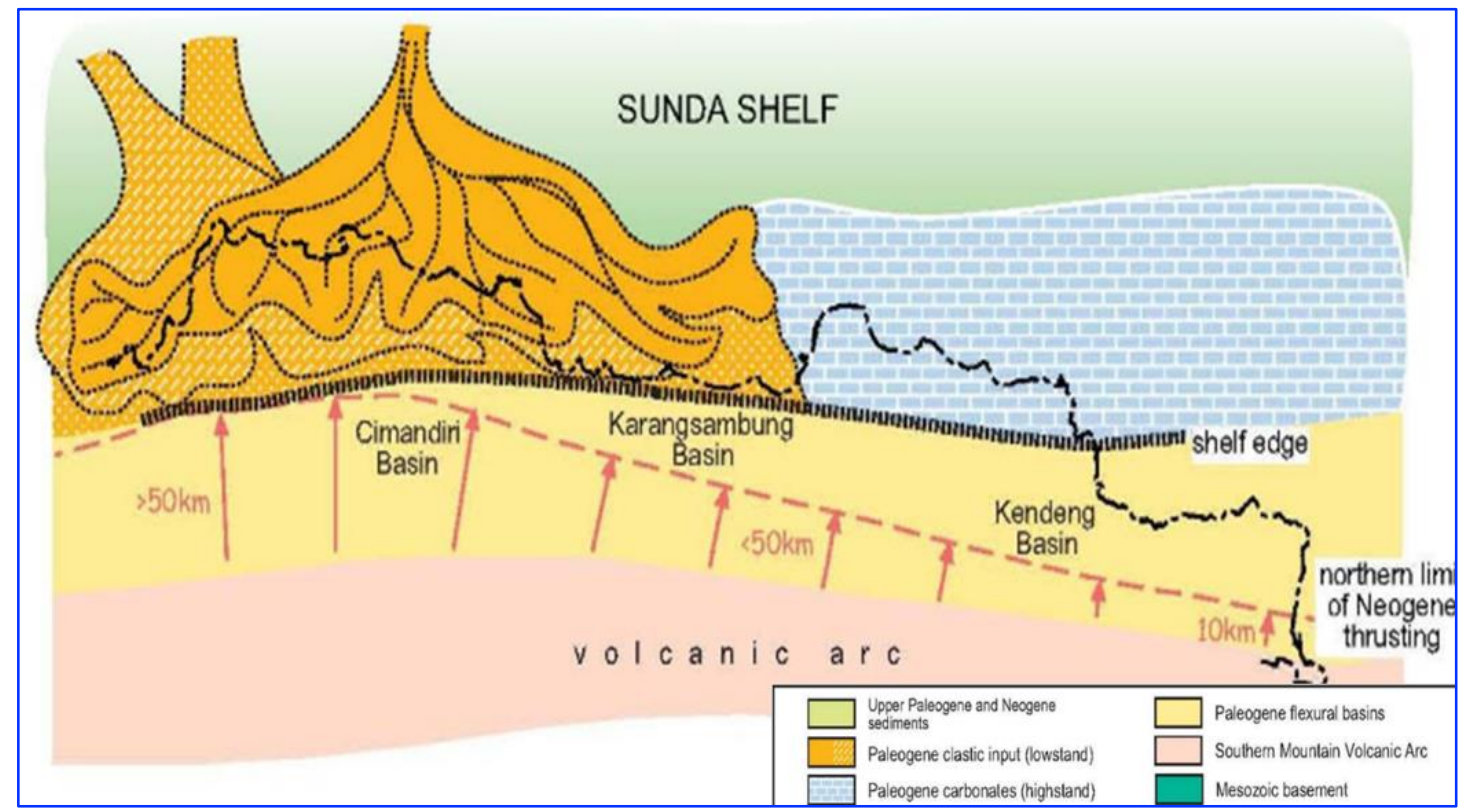

Fig. 2. Schematic image shows the northward thrusting in the south of Java that moved the Paleogene volcanic arc further north (Hall et al. 2007)

Northward thrusting in eastern Java is relatively less distinct from the one occurring on the western side. Based on stratigraphic contact, the northward thrusting is indicated by Paleogene outcrops in the Southern Mountains. On the contrary, rocks of the same age are not found in the north (part of the Kendeng Basin). Some have made assumptions about this condition: although field observations show that Quaternary volcanic deposits have developed at the interzonal boundary, the idea that the northern 
zone is part of the footwall of the thrust fault system remains a debatable matter. The development of the northward thrusting can even be traced to the northern margin of the Kendeng Basin that borders the Rembang Basin. The northward thrusting in this location created folds; hence, it is known as the Kendeng fold-thrust belt system. The structural concept of the thrust fault system is also found in several places in the northern part of the Southern Mountain Range. Many pretertiary and Paleogene outcrops are found in Bayat, which is the western part of the Southern Mountain Range and the thrust fault system. Indications of this structure, i.e., the Old Andesite Formation (OAF) contacts that experience substantial deformation, are also found in several locations in the east.

\subsection{Baturagung Mountain Range}

The Baturagung Mountain Range is the western part of the Southern Mountains with a high topography that forms a cuesta with southeast-facing slopes. In the north of the range, a steep slope marks the northern margin of the Southern Mountains (Fig. 3a). Stratigraphically, the mountain range is composed of volcaniclastic sediments from the Oligocene Kebobutak and Semilir Formations. Approximately $2 \mathrm{~km}$ to the north, an important stratigraphic relationship is found, viz. pretertiary basement complex in Jiwo Hills (Bayat) that appears an outcrop. Many scholars have explained the concept of the Compressive Tectonic Play that forms the Baturagung Mountain Range. Compressive tectonic play is identified by the broad anticline structure with northward upthrust at the base of this anticline. Similarly, Van Bemmelen, (1949) interprets the Baturagung Mountain Range as a result of northward transformation from a normal fault to a wide monocline due to Listrik fault in Wonosari Basin (Husein et al. 2008).

Evidence of the compressive tectonic play can be found in the Tegalrejo thrust fault system (Husein et al. 2008), which changes the steep physiography of the Baturagung Mountain Range into the lowlands in the north (Klaten), wherein pretertiary rock complex is visible on the surface. There are seven thrust faults at this location forming the imbricate fan and duplex structures. A previous simple stereographic analysis concludes that the thrust fault system has moved the coarse sandstone from the SSE direction or approximately $\mathrm{N} 073^{\circ} \mathrm{E}$ (Fig. 3b). At a nearby location, a plunging anticline forms a fault-propagation fold system, which is steep in the north. The fold axis shows the NE-SW direction due to the compressive force coming from the NW-SE direction. The force in question has the same direction as the thrust fault system found in the Tegalrejo area; thus, it can be inferred that the same compression event is responsible for the two structures and produces the fold-thrust belt system that forms the Baturagung Mountain Range.

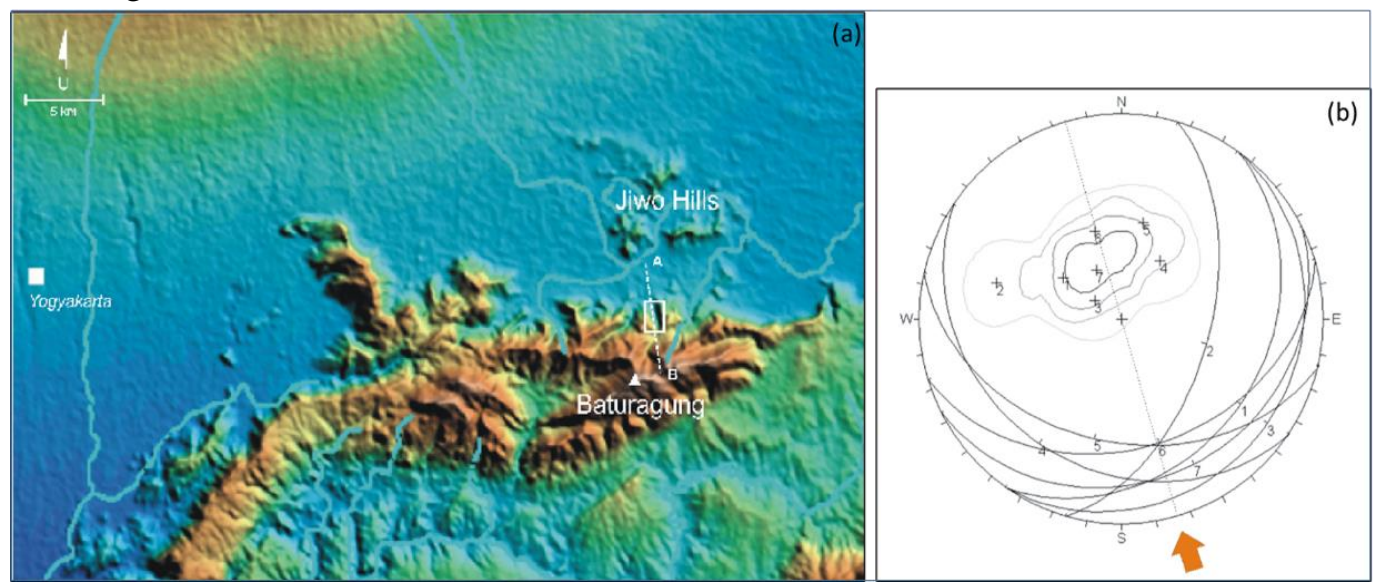

Fig. 3. (a) Physiography of the Baturagung Range ;(b) stereograph projection show the direction of the Tegalrejo-Bayat Thrust Fault System movement. The direction of the stress indicates that it originates from the $\mathrm{SSE}\left(\mathrm{N} 073^{\circ} \mathrm{E}\right)$, perpendicular to the acting force, and proves the concept of compressional tectonics in this region (Hussein et al. 2008). 


\subsection{Wonosari Trough}

The Oligocene volcanic activity producing the constituent rocks of the Baturagung Mountain Range began to weaken in the Lower-Middle Miocene (Smyth et al. 2005). This volcanic activity occurred in subaerial to shallow marine environments. Simultaneously, with the end or weakening of this tectonic activity, the Sambipitu, Wonosari, and Kepek Formations were deposited discontinuously (or in unconformity) in the Wonosari Trough. The Wonosari Trough is interpreted as a narrow basin bordered by the Baturagung Mountain Range to the north and the Carbonate Platform of the Wonosari Formation to the south (Hall et al. 2007). It extends as far as $45 \mathrm{~km}$ with a relative east-west direction and a width of approximately 5-10 km. Its northern and southern highs are thought to supply most volcanic-rich sediments and carbonate fragments of Sambipitu and Kepek Formations that are deposited in the trough.

Sambipitu Formation is composed of rocks rich in volcanic material and contains minute amounts of carbonate deposited in a turbidite system. Currently, the formation has level topography and is bordered by mountains with steep reliefs that are part of the Baturagung Mountain Range north of the southern mountain range. The stratigraphy of the boundary shared by the Sambipitu Formation and the Baturagung Mountain Range cannot be clearly explained because of the sudden change from the volcanic deposits stretching from the subaerial to shallow marine environments of the Baturagung Mountain Range to the deep-sea deposits of Sambipitu Formation with a turbidite system (Hall et al. 2007). On the other hand, in the south, Kepek Formation contains more carbonate material resulting from the breaking down of the Wonosari Carbonate Platform. This formation is composed of turbidite sequences rich in carbonate debris that gradually changes from the Wonosari Formation. This geological overview shows a sudden change from shallow to deep-sea deposits, implying rapid local subsidence that forms a narrow and deep basin following the end of volcanism in the Oligo-Miocene. In addition, the sudden change indicates a compressive tectonic concept that generates thrust faults in the southern mountain range. The northward thrust fault uplifted the southern part and formed a basin in the north. As a result, the Wonosari Platform experienced northward thrust fault, covering the Sambipitu Formation (Fig. 4) (Hall et al. 2007).

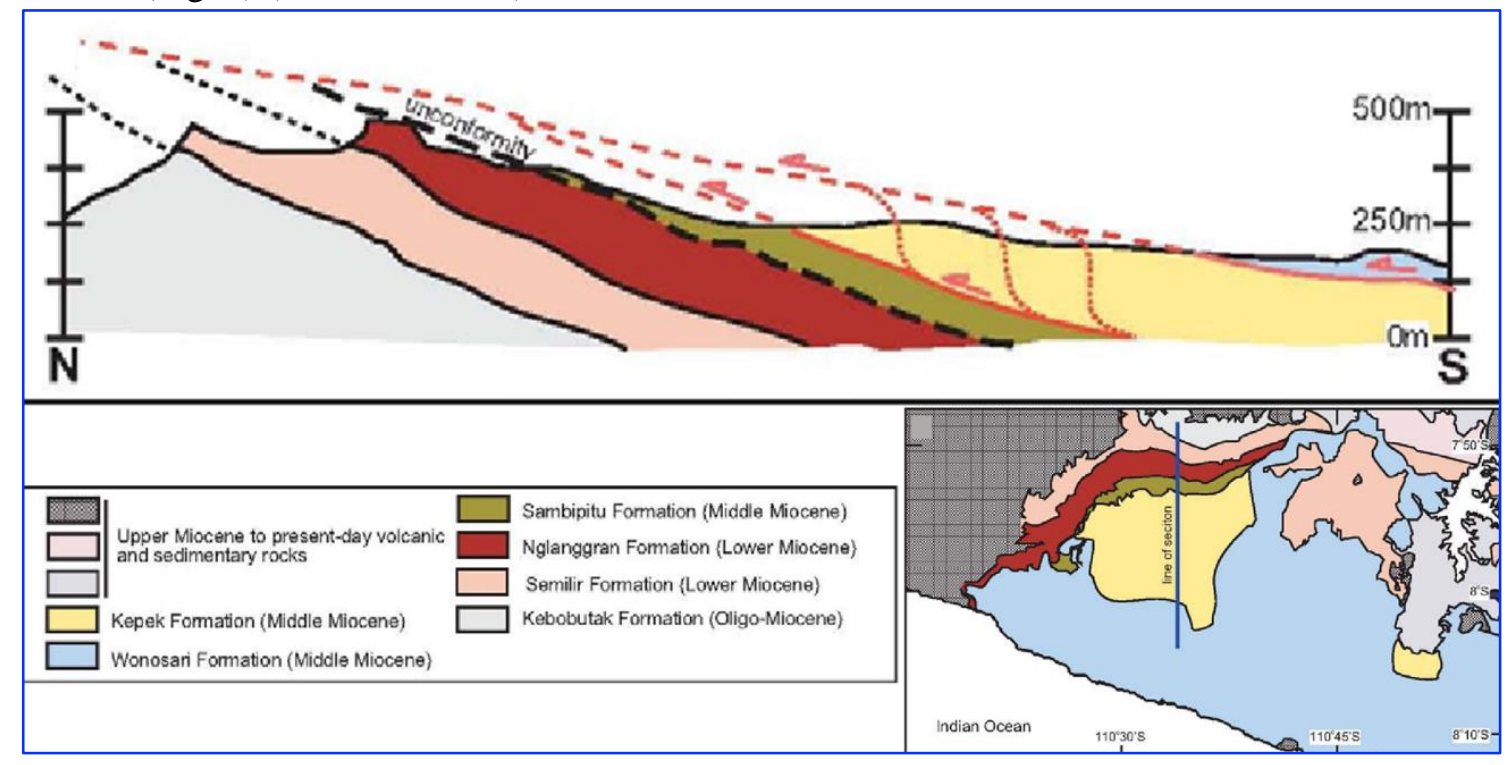

Fig. 4. Schematic cross-sections interpret the thrust fault system of the limestone of the Wonosari, Kepek, and Sambipitu Formations as parts of the Wonosari Trough deposits and the underlying Lower Miocene volcanic rocks (Hall et al. 2007). 


\subsection{Prigi Deformation}

Prigi is located in eastern Java, notably east of the Southern Mountain Range. The stratigraphy of this area begins with the deposition of volcanic rocks from the Lower Miocene Mandalika Formation and is followed by the deposition of the Campurdarat Formation. The Campurdarat Formation is dominated by limestone with clay inserts and is volcaniclastic (Smyth et al., 2005). Limestone contains volcaniclastic debris and faunal assemblage-indicating Middle Miocene-which in some places show a slumping structure. Geology interpretation defines the depositional environment of this formation as shallow seas close to volcanic sources, meaning that the environment contains a mixture of volcanic debris and shallow marine bioclasts. The Mandalika and Campurdarat Formations generally show a small dip sloping to the south. Some places show strong deformation that generated a plunging fold with a low angle towards the northwest (Hall et al. 2007). The strong deformation indicates a thrust fault at the base of the Southern Mountains zone.

Field observations indicate the presence of compressive tectonics along the Southern Mountains. Hall et al. (2007) reconstructs the process by which compressive tectonics generated major thrusting in southern Java that displaced Paleogene volcanic rocks to the north (Fig. 2). The intensity of the major thrusting becomes increasingly larger to the west, wherein the magnitude of the northward thrusting ranged from $10 \mathrm{~km}$ in East Java to $50 \mathrm{~km}$ in West Java (Hall et al. 2007). The thrusting is thought to occur in the Early Miocene, and the formation process possibly lasted for more than one period, which coincided with the cessation of the Paleogene volcanic phase in Java-as marked by the Australia-SE Asia collision in eastern Indonesia (Hall et al. 2007).

\section{Materials and Methods}

Several geologists have put forward the interzonal boundary between the Southern Mountains and the Kendeng Basin. Van Bemmelen, (1949), physiographically defines the northern margin of the Southern Mountains as a volcanic deposit zone identified as the Ngawi subzone (Fig. 1.). The gravity data show another pattern where the Southern Mountains zone is directly adjacent to the low gravity anomaly area in the Kendeng Basin in the north; hence, it can be inferred that the boundary between the two zones is relatively more to the south (Smyth et al., 2008). The subsurface geological conditions cannot be clearly identified at this boundary as it is nearly entirely covered by Quaternary volcanic deposits. As a result, the northward distribution of Oligo-Miocene outcrops in the Southern Mountains (to the Kendeng Basin) is unknown. Similarly, the subsurface continuity of the thrust fault concept that is otherwise visible on the surface from the south to the middle of the Southern Mountains and controls the development of geological structures in the two basins cannot be precisely defined. Therefore, the position of the structural boundary separating them has not been determined due to the overlying Quaternary volcanic deposits.

Indications of subsurface faults, notably those separating the two basins, are revealed in this study based on the derivative analysis of the gravity data, as shown in the research flow chart in Fig. 5. The gravity data used is based on measurements made by the Geological Research and Development Center, Indonesia, that are presented in the Bouguer anomaly map on Surakarta, Ponorogo, and Madiun sheets. The Bouguer anomaly comprises local and regional gravity anomalies or, to simplify, shallow and deep gravity anomalies. Structures affecting the geological order in this area are interpreted as related to the basement development in the study area, meaning that the gravity data analysis needs to focus on regional anomalies. This analysis started with filtering to separate regional and residual anomalies. The derivative analysis of the regional gravity anomaly aimed to highlight the effects produced by faults. Horizontal and vertical derivative analyses are often used to increase the anomaly at the boundary of an anomaly source (Sumintadireja et al. 2018). For instance, an anomaly source may be caused by the presence of faults or the boundary of a sedimentary basin. 


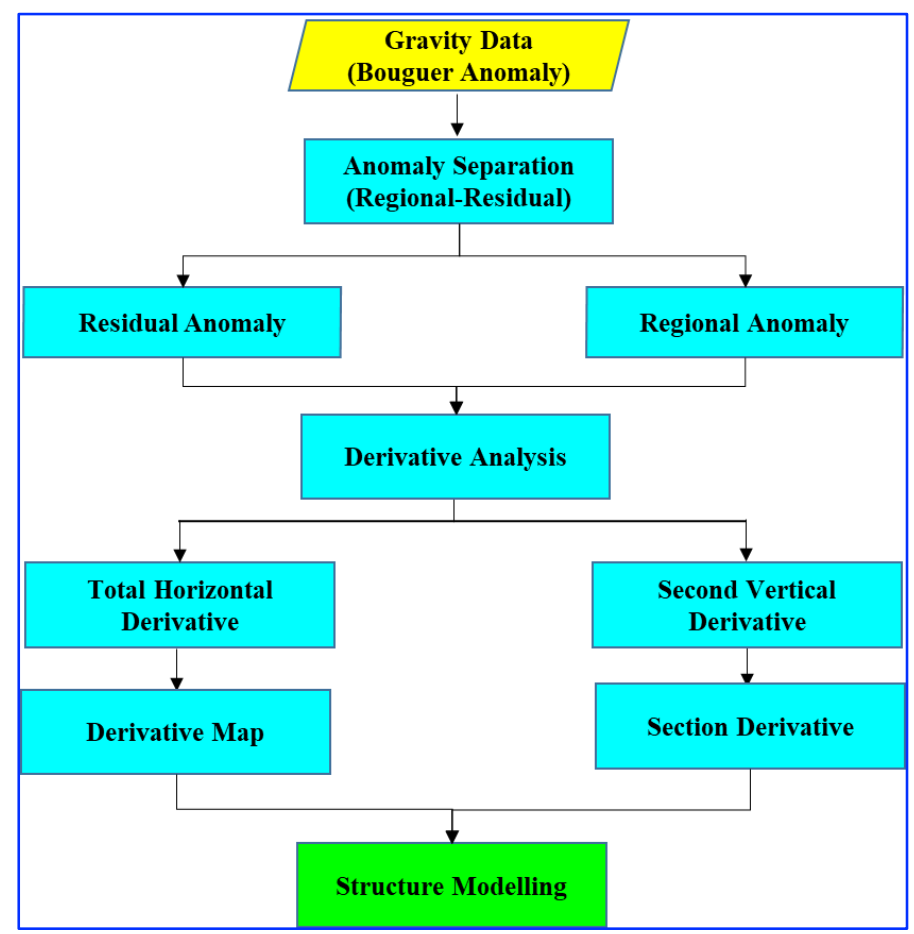

Fig. 5. Research methodology flow diagram

Second Vertical Derivative (SVD) is often used to enhance fine-sized features that are not visually visible in the original gravity data. The results, both gradient and magnitude, can be used to describe the boundary of the anomaly caused by the fault observed. A high gradient is associated with a large contrast of physical properties and vice versa, in subsurface conditions (Sumintadireja et al. 2018). SDV can be calculated in Fourier (wavenumber) and spatial domains. In the Fast Fourier Transform domain, the derivatives of all directions can be calculated. This process increases the high-frequency components in the gravity data, as shown in the equation below:

$$
\frac{\partial^{2} \mathrm{~g}_{\mathrm{z}}}{\partial \mathrm{z}^{2}}=\mathrm{F}^{-1}\left(|\mathrm{k}|^{2} \mathrm{G}_{\mathrm{z}}\right) \quad \text { with } \quad|\mathrm{k}|^{2}=\mathrm{k}_{\mathrm{x}}^{2}+\mathrm{k}_{\mathrm{y}}^{2}
$$

where $\mathrm{Gz}$ is the Fourier transform of $\mathrm{gz}, \mathrm{kx}$ and $\mathrm{ky}$ are wavenumbers on the $\mathrm{x}$ and $\mathrm{y}$ axes, respectively, and F-1 is the inverse operator of the Fourier transform. SVD can also be computed in the spatial domain of its horizontal gradient using the Laplace equation:

$$
\frac{\partial^{2} g_{z}}{\partial z^{2}}=-\left(\frac{\partial^{2} g_{z}}{\partial x^{2}}+\frac{\partial^{2} g_{z}}{\partial y^{2}}\right)
$$

Bott, 1962, has developed simple criteria for interpreting gravity anomalies based on the SVD's relative magnitude or [g"] in the 1D gravity profile. For example, the SVD value of the gravity anomaly at the two-dimensional horizontal slab with a sloping edge at the position $(x, 0)$ can be written as:

$$
g^{\prime \prime}=-2 K \rho \sin i\left[\frac{\left(x_{1}-x\right) \sin i-z_{1} \cos i}{\left(x_{1}-x\right)^{2}+z_{1}^{2}}-\frac{\left(x_{2}-x\right) \sin i-z_{2} \cos i}{\left(x_{2}-x\right)^{2}+z_{2}^{2}}\right]
$$

where $\mathrm{K}$ is the gravitational constant, $\rho$ is the rock's density contrast, $\mathrm{i}$ is the angle of inclination of the rock unit measured from a horizontal plane, and $(\mathrm{x} 1, \mathrm{z} 1)$ and $(\mathrm{x} 2, \mathrm{z} 2)$ are the coordinates of the upper and lower boundaries of the rock unit (Fig. 6). Bott's simple criteria are as follows: when $|\mathrm{g} " \max |$ is greater than $|\mathrm{g} " \mathrm{~min}|$, then the anomaly can be attributed to a sedimentary basin with an inward sloping 
edge, whereas if $|g " \max |$ is smaller than $|\mathrm{g} " \mathrm{~min}|$, then the source of the anomaly is a granite pluton with an outward sloping edge. This study can be applied to fault analysis, especially in determining the direction of the fault's slope but not the fault type (Sumintadireja et al. 2018).

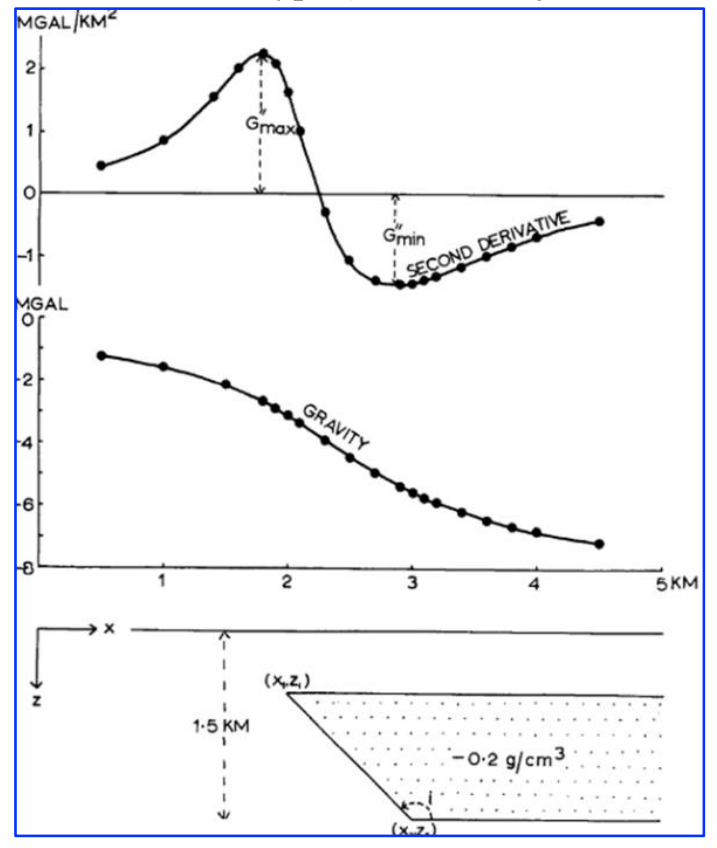

Fig. 6. Gravity anomaly and SVD responses to the rock slope model wherein the SVD value (g") reaches its maximum when $\rho$ is negative (indicating a basin), decreases to the minimum value, then finally rises again asymptotically to zero (Bott, 1962)

\section{Results and Discussion}

The subsurface boundary between the Southern Mountains and the Kendeng Basin was determined using the derivative method. Surface data identified that the two Quaternary volcanoes, Mount Wilis and Mount Lawu, produce volcanic deposits covering almost the entire interzonal boundary. Although surface identification of said boundary is not feasible, the west-east volcano lineage between Mount Lawu and Mount Wilis and several parallel volcanoes may indicate a weak zone through which magma emerges as a volcano. Fig. 7 shows the results of the horizontal derivative analysis of the gravity data. Total Horizontal Derivative (THD) solidifies fine-sized features on the fault boundary plane, allowing the fault-associated boundary anomalies to produce strong derivative anomalies. Based on the horizontal derivative analysis, the boundary between the Southern Mountains and the basin in the north showed a strong lineage anomaly and is interpreted as a west-east trending major fault continuity (red line). Bouguer anomaly map, showed a contrasting pattern between the zones. The Southern Mountains were characterized by a high gravity anomaly between 130-50 mGal, while the Kendeng Basin had a much lower value of up to $-50 \mathrm{mGal}$. This major fault limits the high Bouguer gravity anomaly area in the south with a low anomaly area in the north in subsurface conditions (Fig. 8). The major fault boundaries cannot be clearly identified on the surface because most of them are covered with Quaternary volcanic deposits. Fig. 9 shows the subsurface fault interpretation plotted on the geological map. Some outcrops that are positionally out of Southern Mountain line indicate the presence of a major fault that displaced them from their zone, e.g., limestone outcrops of the Wonosari Formation on the western slope of Mount Lawu. This limestone is interpreted as moving northward from the Southern Mountains due to a thrust fault. Another indication is the presence of breccia outcrops of the Old Andesite Formation (OAF) group on the eastern side of Mount Lawu (Rachman, 2017). The outcrops are known to be the northernmost of the OAF outcrop group in the south, which is thought to have moved from its initial position due to a thrust fault. 


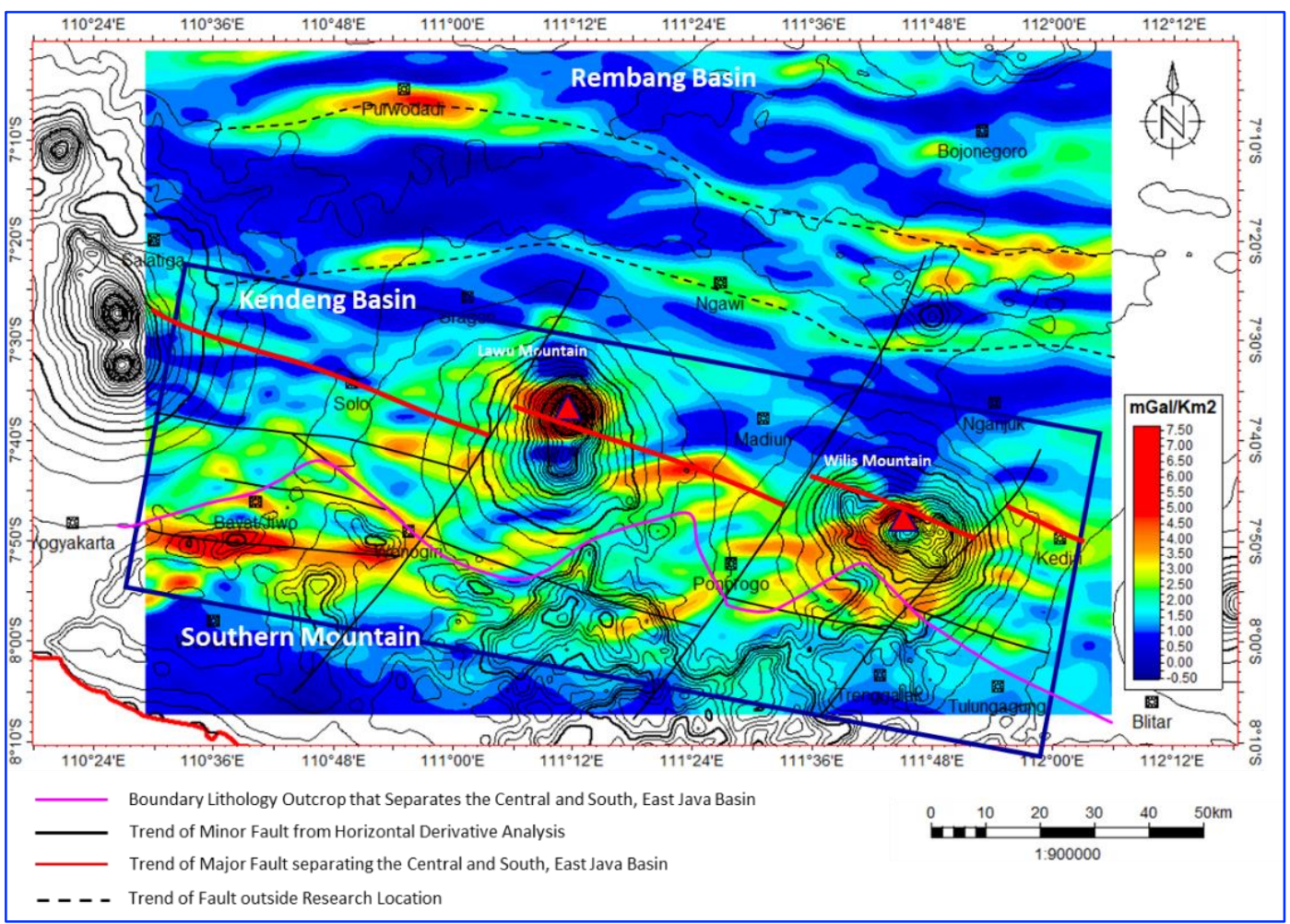

Fig. 7. Horizontal derivative analysis results show the boundary structure line between the Kendeng Basin and the Southern Mountains. This structure extends in a relative west-east direction (The blueline box marks the research location)

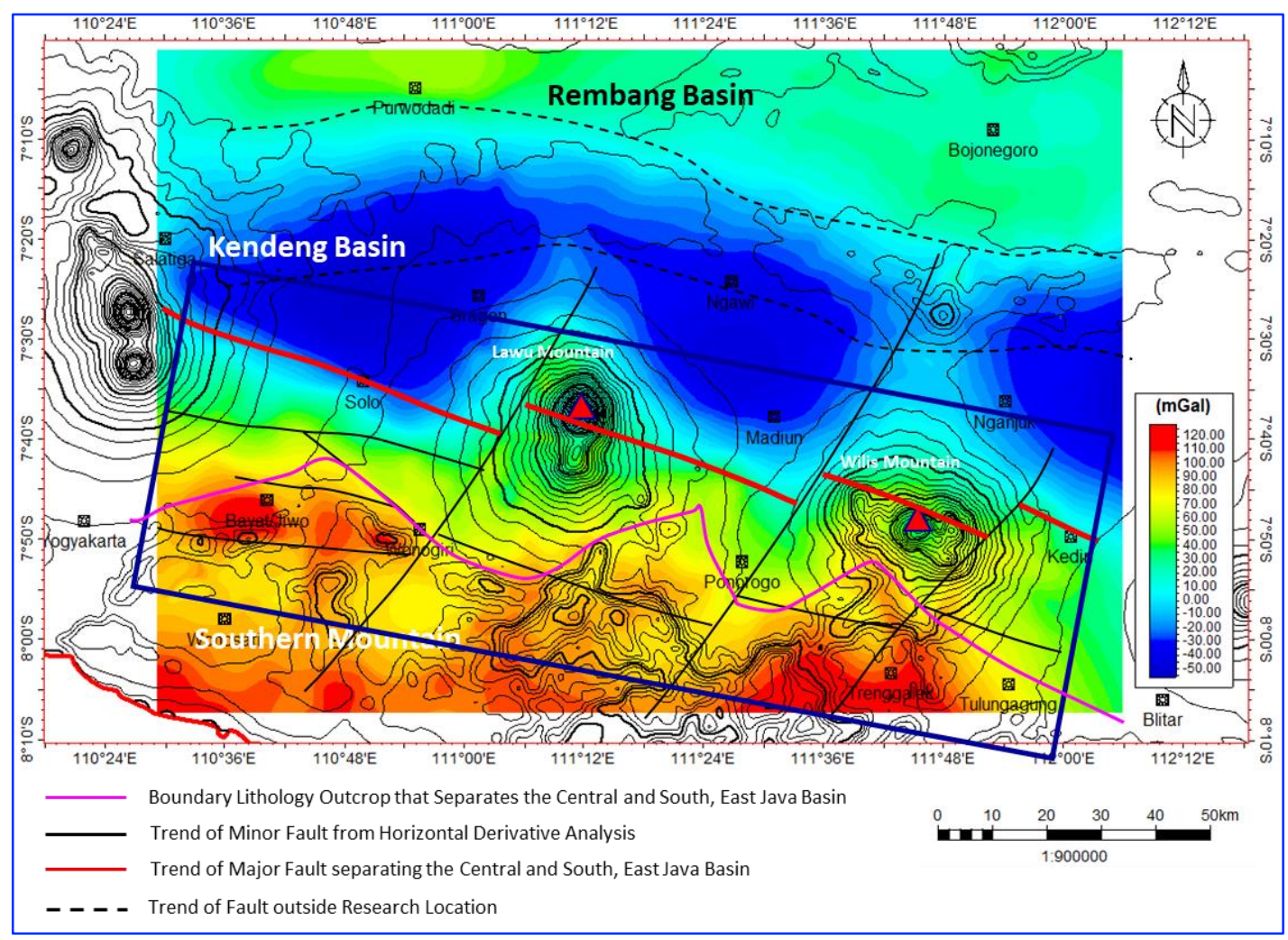

Fig. 8. Fault interpretation from THD plotted on Bouguer Anomaly map. This major fault limits the high Bouguer gravity anomaly area in the south with a low anomaly area in the north (The blue-line box marks the research location) 


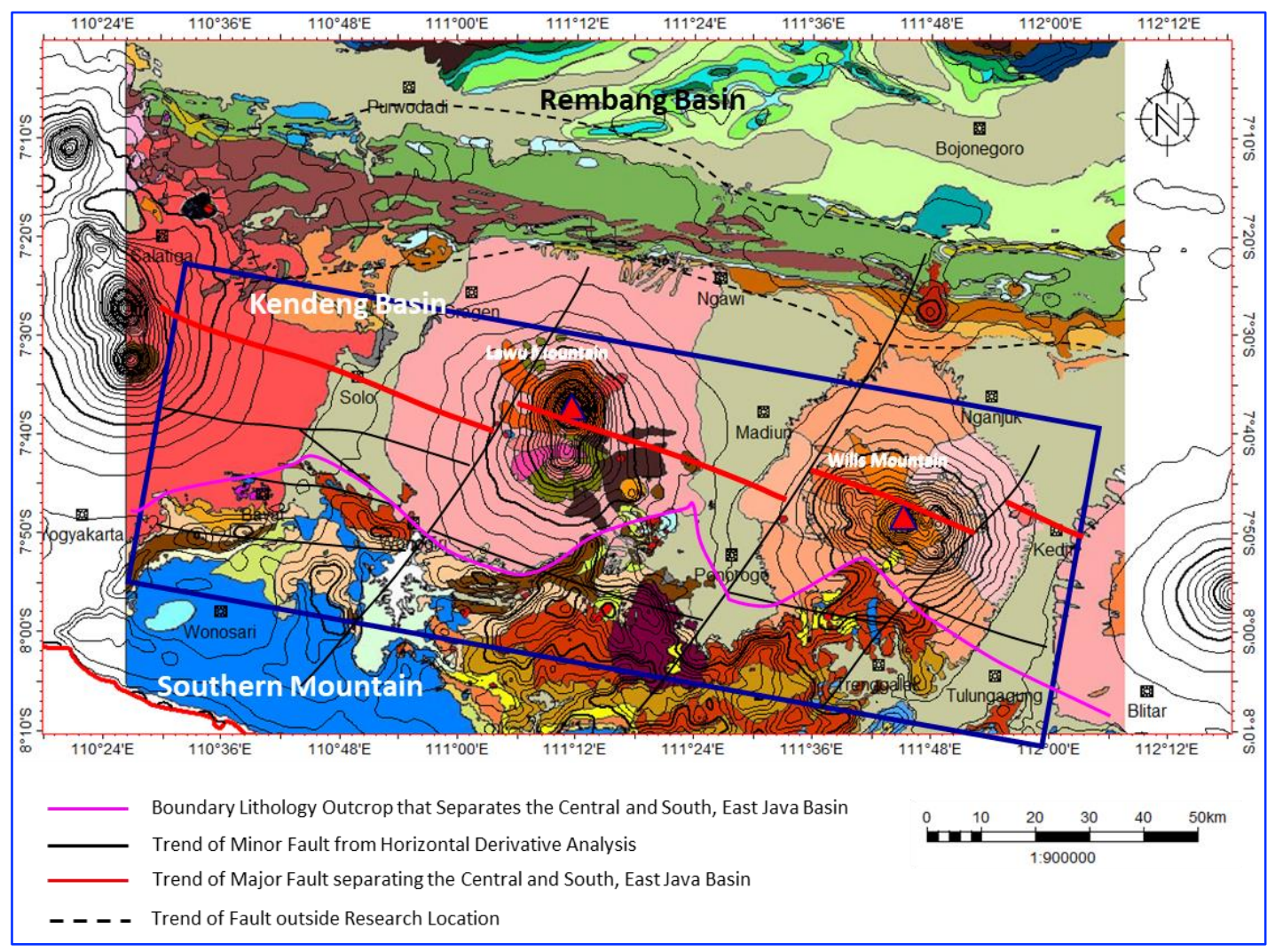

Fig 9. The subsurface fault interpretation plotted on the geological map. (The blue-line box marks the research location)

The SVD analysis was also applied to support the other derivative analyses. Both SVD and THD analyses confirm the anomaly identified in the fault boundary plane. The research created SVD crosssections of two selected tracks to determine the slope pattern of the faults identified in the derivative analysis. Combined with the density value, the absolute minimum and maximum SVD values show the slope gradients of the fault observed (Tables 1 and 2). Based on Bott's criteria, the fault slope is predominantly southward (Fig. 10a and 11a). This analysis result corresponds to the geological studies wherein the direction of stress induced by compressional tectonics from the Australia-Sundaland interaction is thought to form a thrust fault that tilts southward and a fold-thrust belt along the Southern Mountains and Kendeng Basin. The 2.5D gravity modeling produced the conceptual geological model of the fold-thrust belt formation, which shows a major fault with a south-facing slope that separates the two zones and forms the fold-thrust belt system with a steep slope in the south that slants down toward the south (Figs. $9 \mathrm{~b}$ and 10b).

Table 1. SVD calculations for fault direction identification on line 1

\begin{tabular}{cccccc}
\hline No & |SVD min | & |SVD max & $\begin{array}{c}\text { Density 1 } \\
\text { (North) }\end{array}$ & $\begin{array}{c}\text { Density 2 } \\
\text { (South) }\end{array}$ & $\begin{array}{c}\text { Dip Fault } \\
\text { Orientation }\end{array}$ \\
\hline F1 & $-0,9$ & $-0,2$ & $-39,8$ & $-35,6$ & South \\
F2 & $-0,7$ & $-0,09$ & 13,2 & 64,5 & South \\
F3 & $-0,9$ & 0,4 & 162 & 341,1 & South \\
F4 & 1,6 & 2,8 & 520,9 & 487,8 & South \\
F5 & $-2,2$ & 1,8 & 424,4 & 99,5 & North \\
F6 & $-0,2$ & 0,07 & $-81,5$ & $-88,2$ & South \\
F7 & $-0,1$ & 0,3 & $-96,6$ & $-119,4$ & South \\
\hline
\end{tabular}




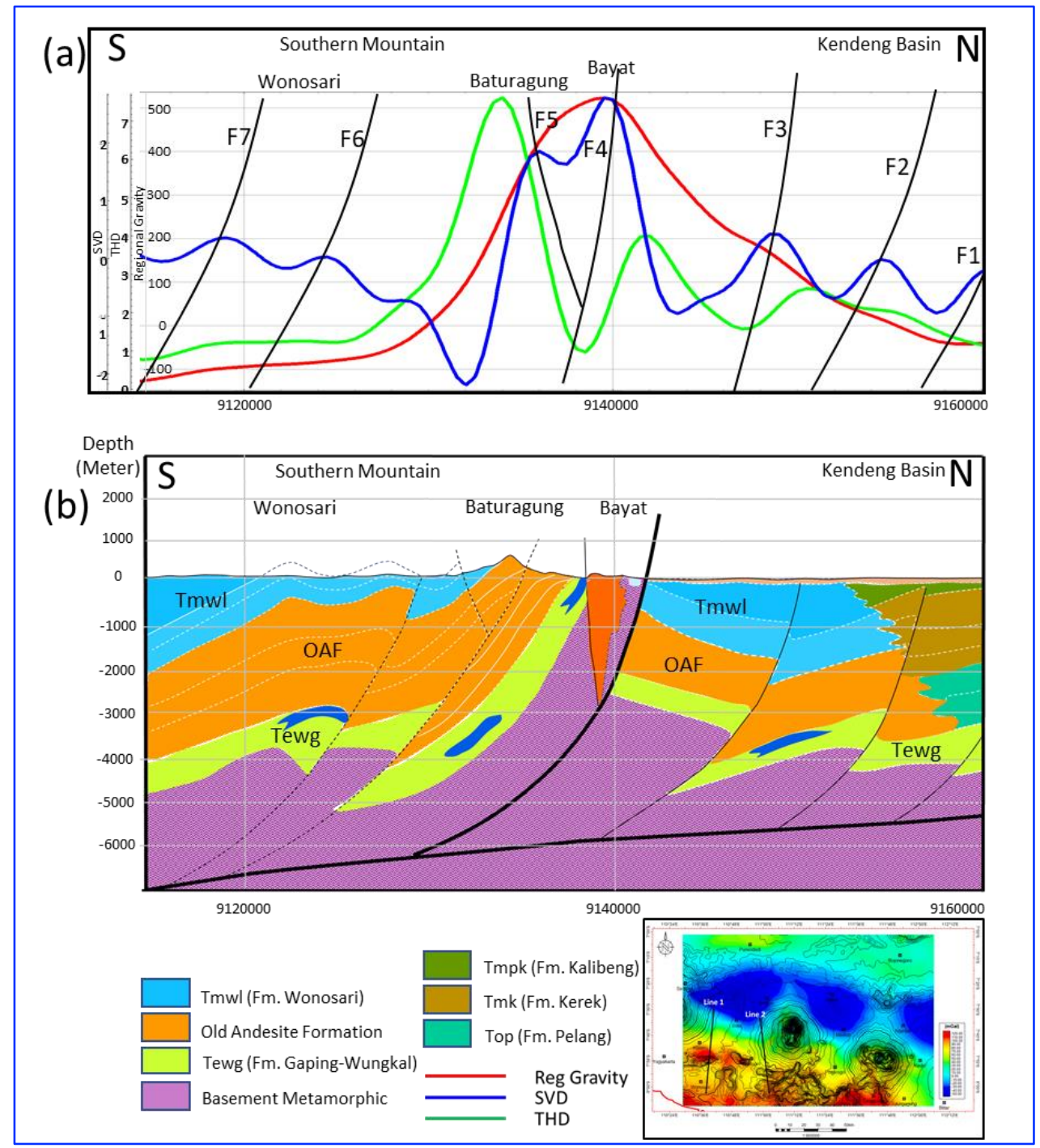

Fig 10. (a) A cross-section derived from the vertical derivative analysis results shows the fault slope direction on Line 1; (b) The geological model demonstrates the developing structural pattern in the Southern Mountains and Kendeng Basin.

Table 2. SVD calculations for fault direction identification on line 2

\begin{tabular}{lccccc}
\hline No & |SVD min | & |SVD max | & $\begin{array}{c}\text { Density 1 } \\
\text { (North) }\end{array}$ & $\begin{array}{c}\text { Density 2 } \\
\text { (South) }\end{array}$ & $\begin{array}{c}\text { Dip Fault } \\
\text { Orientation }\end{array}$ \\
\hline F1 & $-0,75$ & 1,06 & 18,7 & $-77,7$ & South \\
F2 & $-0,32$ & $-0,09$ & $-92,6$ & $-77,9$ & South \\
F3 & $-0,6$ & 0,22 & $-55,3$ & $-38,1$ & South \\
F4 & 0,28 & 0,35 & 37,2 & 32,9 & South \\
F5 & $-0,8$ & 1,04 & 38,9 & $-55,8$ & South \\
F6 & $-0,21$ & 0,49 & $-30,8$ & $-31,8$ & South \\
F7 & $-1,11$ & 1,32 & -11 & $-111,2$ & South \\
\hline
\end{tabular}




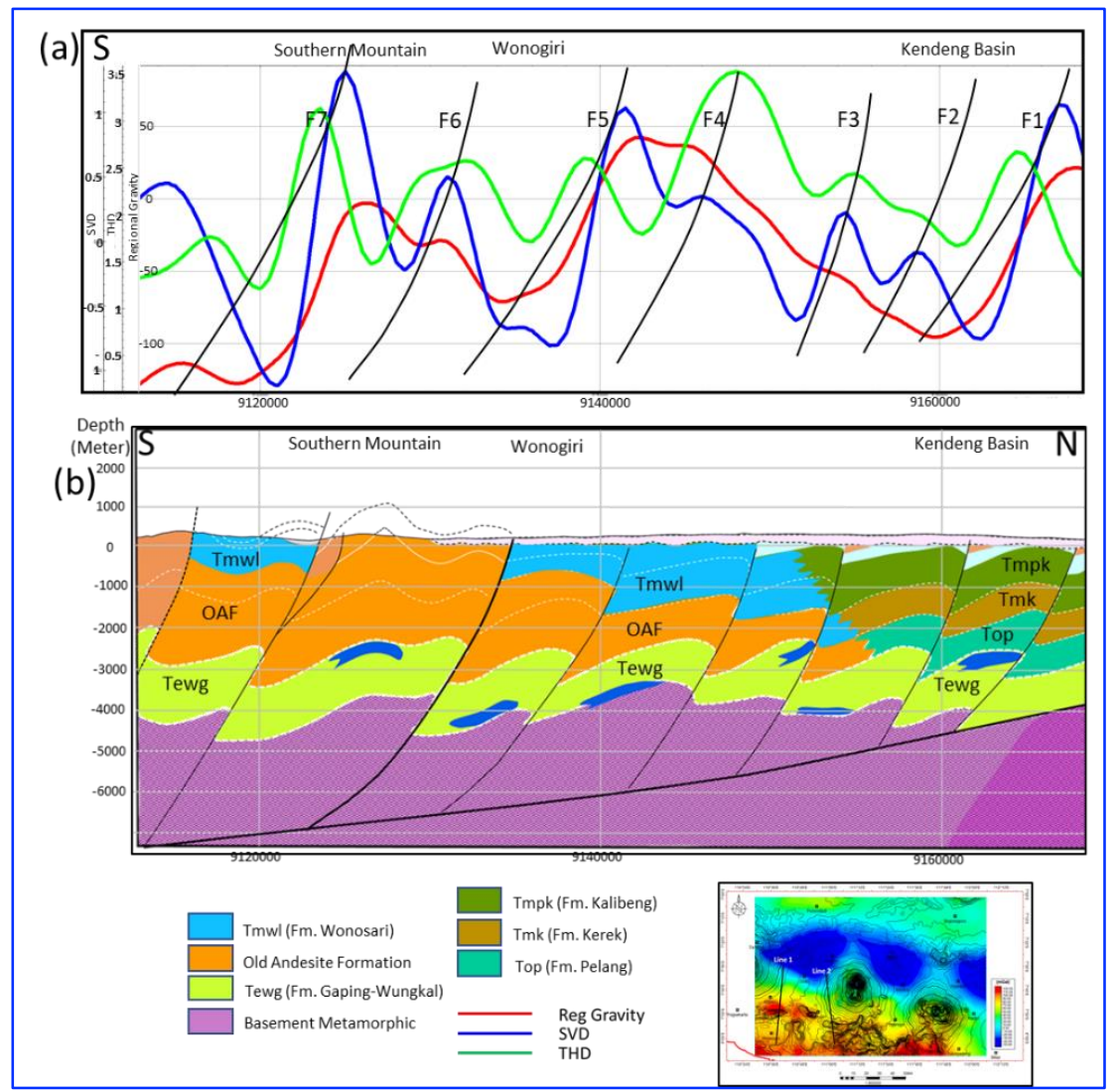

Fig. 11. (a) A cross-section derived from the vertical derivative analysis results shows the fault slope direction on Line 2; (b) The geological model demonstrates the developing structural pattern in the Southern Mountains and Kendeng Basin

\section{Conclusions}

Eastern Java is formed by the compressive tectonics occurring in several periods in the Cenozoic due to the interaction between the Gondwana microcontinent and southeastern Sundaland. The compressive tectonics generate northward thrusting along southern Java and form the fold-thrust belt system that expands northward to the Kendeng Basin. Indications of this tectonic activity have long been identified, but the thick Quaternary volcanic deposits mask its precise boundaries. Based on the total horizontal derivative analysis results, the anomaly shows a west-east continuity interpreted as a fault continuity the suspected boundary separating the Southern Mountains and the Kendeng Basin in the north. Further, the second vertical derivative analysis results show that the major fault interpreted as the interzonal boundary has a dominantly south-facing slope, which corresponds to the stresses acting along the island of Java. The conceptual model made by $2.5 \mathrm{D}$ gravity data modeling shows that the fault forms a fold-thrust belt system with the angle of the fault plane slanting down northward. This thrusts fault concept can explain how the rock constituents of the Southern Mountains can move from the main path and shift further north.

\section{Acknowledgments}

The authors are grateful to the Indonesian Geological Research and Development Center for publishing accessible data for this research, The authors are very grateful to the reviewers, Editor in Chief Prof. Dr. Salih M. Awadh, the Secretary of Journal Mr. Samir R. Hijab, and the Technical Editors for their great efforts and valuable comments. 


\section{References}

Awadh, S.M., Ali, K.K. and Alazzawi, A.T., 2013. Geochemical exploration using surveys of spring water, hydrocarbon and gas seepage, and geobotany for determining the surface extension of Abu-Jir Fault Zone in Iraq: A new way for determining geometrical shapes of computational simulation models. Journal of Geochemical exploration, 124, 218-229.

Bott, M.P.H., 1962. A simple criterion for interpreting negative gravity anomalies, Geophysics, 27(3), 376-381.

Hall, R., Clements, B., Smyth, H.R., Cottam, M.A., 2007. A new interpretation of Java's Structure, Proceedings of Indonesian Petroleum Association Thirty-First Annual Convention and Exhibition, G-035.

Husein, S., Mustofa, A., Sudarno, I., Toha, B., 2008. Tegalrejo Thrust Fault as an indication of compressive tectonics in Baturagung Range, Bayat, Central Java, $37^{\text {th }}$ Annual Convention IAGI, 258-268.

Prasetyadi, C., Rachman, M. G., Hapsoro, S. E., Shirly, A., Gunawan, A., and Purwaman, I., 2016. Seismic-based structural mapping of RMKS Fault Zone: implication to hydrocarbon accumulation in East Java Basin, Proceedings Geosea XIV And 45 ${ }^{\text {th }}$ IAGI Annual Convention, 104-107.

Rachman, M.G., 2017. Evolusi Tektonik Pegunungan Selatan Jawa Bagian Timur, thesis, Pembangunan Nasional "Veteran" Yogyakarta University.

Setiaji, R.A., Andhika C.A., Aulia, K.N., Radityo, D., Arifullah, E., 2016. The Stratigraphic Significance of Glossifungites Ichnofacies in Cipari Area, Central Java, Proceedings Geosea XIV And $45^{\text {th }}$ IAGI Annual Convention (GIC 2016), 540-543.

Smyth, H.R., Hall, R., and Nichols, G.J., 2008. Cenozoic Volcanic arc history of East Java, Indonesia: the stratigraphic record of eruptions on an active Continental Margin, The Geological Society of America, Special Paper 436, 199-222.

Smyth, H.R., Hall, R., Hamilton, J., and Kinny, P., 2005. East Java: Cenozoic Basins, volcanoes and ancient basement, Proceedings of Indonesian Petroleum Association. Thirtieth Annual Convention \& Exhibition, 251-266: G-045

Sumintadireja, P., Dahrin, D., and Grandis, H., 2018. A note on the use of the Second Vertical Derivative (SVD) of gravity data with reference to indonesian cases, Journal Engineering Technology Science, 50 (1), 127 139.

Van Bemmelen, R.W., 1949. The Geology of Indonesia. Vol 1A. General Geology of Indonesia And Adjacent Archipelagos, Martinus Nijhoff, The Hague, Netherlands.

Waltham, D., Hall, R., Smyth, H.R., and Ebinger, C.J., 2008. Basin formation by volcanic arc loading, The Geological Society of America, 436, 11-26. 